\title{
THE USE OF PEER EDITING TECHNIQUE TO IMPROVE STUDENTS' WRITING
}

\author{
Dedi Irwan ${ }^{1}$, Sulaiman ${ }^{2}$ \\ ${ }^{1}$ IKIP PGRI Pontianak, ${ }^{2}$ IAIN Pontianak \\ correspondence email: sulaimaniainptk@gmail.com
}

\begin{abstract}
This research aimed to investigate how Peer Editing technique can improve students' writing to the second semester students of Islamic education study program of IAIN Pontianak. This classroom action research was done in two cycles. Then, the subject of research was the students of class A consisting of 34 students with detail of 10 male students and 24 female students. This research used observation and measurement as the technique of collecting data. The qualitative data were taken from observation checklist, field note, and recorder while quantitative data were taken from the students' writing test. Then, in analyzed the data, the writer used descriptive qualitative analysis to the qualitative data and statistic descriptive to the quantitative data. The results of this research showed that the implementation of the Peer Editing technique was successful to improve the students' writing skill. Through Peer Editing technique, the students were able to generate and organized their ideas and produce a text as well. It is better for the lecturer implemented the Peer Editing technique as the alternative ways to improve students writing skill.
\end{abstract}

Keywords: Writing skill, Peer Editng technique, IAIN Pontianak

\begin{abstract}
Abstrak
Penelitian ini bertujuan untuk mengetahui bagaimana teknik Peer Editing dapat meningkatkan penulisan mahasiswa untuk mahasiswa semester dua program studi pendidikan Agama Islam di IAIN Pontianak pada tahun akademik 2016/2017. Penelitian tindakan kelas ini dilakukan dalam dua siklus. Setiap siklus terdiri dari empat tahapan; perencanaan, tindakan, mengamati, dan evaluasi. Subjek penelitian adalah mahasiswa kelas A yang terdiri dari 34mahasiswa dengan perincian 10 mahasiswa pria dan 24 mahasiswa wanita. Penelitian ini menggunakan observasi dan pengukuran sebagai teknik pengumpulan data. Dalam mengumpulkan data, penulis menggunakan data kualitatif dan kuantitatif. Data kualitatif diambil dari daftar observasi, catatan lapangan, dan perekam sementara data kuantitatif diambil dari tes menulis mahasiswa. Kemudian, dalam menganalisis data, penulis menggunakan analisis deskriptif kualitatif untuk data kualitatif dan statistik deskriptif dengan data kuantitatif. Hasil penelitian ini menunjukkan bahwa penerapan teknik Peer Editing berhasil meningkatkan keterampilan menulis mahasiswa. Melalui teknik Peer Editing, para mahasiswa dapat menghasilkan dan mengatur ide-ide mereka dan menghasilkan teks juga. Salah satu saran yang baik bagi dosen untuk menerapkan teknik Peer Editing sebagai cara alternatif untuk meningkatkan keterampilan menulis mahasiswa.
\end{abstract}

Kata kunci: menulis, teknik Peer Editing 


\section{INTRODUCTION}

Writing is very important as one of the media in communication that can help people to have a good socialization, express their ideas, feelings, and opinions so that people can have a good interaction with their society. According to Hyland (2003:9), "Writing is a ways of sharing personal meanings and writing courses emphasize the power of individual to construct his or her own views on a topic.” Futhermore, Olshtain in Celce-Murcia (2001:207) defines writing as an act of communication which takes place between the writer and the reader via the text in an interactive process. In adition, based on Brown, (2000:335), writing is a written product of thinking, drafting, and revising that require specialized skills. Those make writing become one of the most important skill in learning process.

Alwasilah and Alwasilah in Farianti (2013:1) also said that writing has been proved as language activity that help students to create logical competence, that is the ability to solve problem through complex linguistic and cognitive ability such as organizing, structuring, and revising. Thus, it is clear that writing is one of the most important skill to be mastered. But based on the Researcher's experience conducted pre-observation to the second semester students of Islamic education study program of IAIN Pontianak, it is found that the students still had difficulties in writing. The students could not develop their ideas and even had problems to start writing. Moreover, there were a lot of grammatical errors such as using inappropriate tenses and their writing organization was also low. They often do not use punctuation and make mistake in capitalization. Thus, it can be said that their writing is still need improvement.

Regarding those problems, the students need a technique to help them understanding the mistakes and the correct one. The technique that is needed to improve their writing skill is techniques that can make the students are easier to know the mistakes and later can avoid it to write the correct one. One of the techniques that can make the students improve their writing is Peer Editing. In a good learning-writing process, the students will need some helps to revise or comments on their work from their classmates. It is functioned to see the mistakes of their work and also give some advises and suggestions to their better writing. 
Bartels (2003:34) states that peer review is also referred to as Peer Editing, peer response, peer evaluation, and peer feedback, in which students read each other's writing and provide feedback

The Peer edititng technique has some advantages such as: enhancing students' audience awareness and enabling the students to see egocentrism in their writing, help the students' critical reading and analysis skills, encouraged the students to focus on the intended meaning by discussing the alternative points of view that led to the development of ideas, promote more at the student's level of development and interests by providing more informative messages than lecturer feedback, etc (Kitchakarn 2007:73). In addition, One of the reasons why this technique is used in the study is because it provides the learners a strong sense of group unity and also develops values of caring and sharing among the students. Moreover, they will feel free and comfortable when they do something with their peer group.

The similar studies that had been conducted by the previous researcher. Such as, Fatoni (2014), the result of his study showed that there was improvement of students' writing skill. Most of the students gradually gained good scores at the end of each cycle. In addition, her study showed that students had positive responses to the implementation of Peer Editing technique in the teaching learning process of writing, the class condition during teaching learning process creates the positive atmosphere in the classroom, and also makes students creative in writing. That was the reason that the Researcher believes that using the Peer Editing technique would improve students' writing ability. It was because there were some benefits that were offered by the Peer Editing technique in the English teaching learning process, especially in writing

\section{RESEARCH METHOD}

In term of research methodology, The Researcher will use a classroom action research. According to Tomal (2003:5) "action research is a systematic process of solving educational problems and making improvements". In addition, according to Mettetal (2001:2), classroom action research is a method of finding out what works best in your own classroom so that you can improve student learning. In 
this research, the researcher conducted two cycles to see the improvement of the students' skill in writing by using Peer Editing technique (Burns,1999).

\section{Technique of Collecting Data}

\section{Observation}

According to Khotari (1990:96) states that under the observation method, the information is sought by way of investigator's own direct observation without asking from the respondents. In this research, the researcher observed many things that relate to the research process that can support result of the data. The researcher as lecturer taught the students by using Peer Editing technique and the other lecturer as collaborator observed the students activity in the class during apply Peer Editing technique.

\section{Measurement}

According to Bell (1999:1), a measurement tells us about a property of something. It might tell us how heavy an object is, or how hot, or how long it is, and measurement gives a number to that property and measurements are always made using an instrument of some kind. In this research, the researcher measured the students' writing skill after applied Peer Editing technique.

\section{Tool of Collective Data}

\section{Observation checklist}

Checklists are structured observation tools used when specific, predictable results are expected. According to Ary (2010: 217), checklist presents a list of the behaviors that are to be observed and the observer then checks whether each behavior is present or absent. The researcher used the observation guiding to observe the students' learning and behavior in the class. The data that be obtaind through this observation didn't be processed statistically, but would be analyzed qualitatively.

\section{Field note}

According to Mellon in Westbrook (1994:246), field notes are a data collection tool that contains everything the investigator saw, experienced, and remembered as well as notes on emotions and analytic comments. In this research, this tool would be the perception of the writer towards applying of Peer Editing 
technique in the classroom. The perception can be about the lack of students' interest, activness, and unsual something happen in the class and mistake that will be done by the lecturer during the learning process and others.

\section{Audio recording}

Recorder is used to save all of the information along the research. "Audio or video recording are relatively easy to make and provide a more accurate record of a lesson than checklist or observation (Richards and Farrell 201:97)." In this research, recorder was used to record all the events that happen during the learning process. Kinds of recorder informed of smart phones or tape recorder.

\section{Essay test}

Essay test is a tool to find out the students' ability in writing. According to Ross (2005:36), “A test is an instrument or procedure that proposes a sequence of tasks to which a student is to respond." Based on that statement, the researcher used essay test after applied the teaching technique.

\section{Technique of Analyzing Data \\ Qualitative approach}

The data through observation used three steps for qualitative data analysis which described by Miles and Huberman (1994:10 -11). They proposed that the qualitative analysis involved three steps as follows: data reduction, data displays, and conclusion drawing or verification. in this research, the researcher summarized the data of field note in the stage reduction, and then in the stage display the data, the researcher described and explained based on summarize of field note and result of observation checklist, after that the researcher made a drawing conclusion or verification about the result of field note and observation checklist in the class teaching learning situation.

\section{Quantitative approach}

In quantitative approach, the researcher doing the test or measurement to analyze the data. After got the score of the students, the researcher counting the mean score, as Fraenkel (2012:196) states that "mean is another average of all the scores in a distribution. It is determined by adding up all of the scores and then dividing this sum by the total number of scores". 


\section{RESULT AND DISCUSSION}

\section{The First Cycle}

\section{Observation checklist}

In the observation checklist, the collaborator filled the observation checklist based on the categories of observation checklist. There are three categories, such as students' performance, lecturer' performance and class environment. Each category has some components or statements that were expected emerge by the researcher in the learning process.For the students' performance during learning teaching process was found that a little of students paid attention to the lecturer' explanation about recount text and Peer Editing technique, they still busy with themselves, and also very little of students asked the lecturer about recount text by using Peer Editing, it means that the students was not communicative to the lecturer. Then, a little of students who interested and enthusiastic in learning process, this was because the students still confused and did not understand and also this technique was something new for the students. Furthermore, a lot of students in the group were active and communicative. Even thought like this, very little of students in a group worked together and analyzed the text in pairs, so that why very little of students finished their writing recount text. It caused, only a little the students work properly based on the instruction. After that, very little students asked the lecturer when they have difficulties about the materials. Then, a little students gave response and discuss the draft with their friends and also very little of students asked about learning process during made a recount text.

In the lecturer' performance which The researcher was as lecturer, the lecturer was good enough explained about recount text and Peer Editing. Then, the lecturer also monitored and did the reflection activity. Furthermore, in class environment was found the class was noisy, then a little of students looked joyful and fun. Next, a little of students is activ in learning process, and also a little good interaction between students to students and students to lecturer.

In conclusion, from the data of observation checklist above, the students still did not paid attention during learning process, and also the students confused and did not understand to the lecturer's instructions, as the consequence, the students 
difficult to write recount text and very little of students could finished it. And then, the students did not active and enthusiastic during learning process which was hoped by the researcher that they will make it.

\section{Field note}

In the field note, there were some notes that the collaborator found during learning process. There were three categories of field note, such as students' performance, lecturer's performance and class environment. In students' performance, some of students did not pay attention when the lecturer explained about the material, the student just told each other. Then, there were some students did not interactive when the lecturer asked them to ask about the material. It means that the students were not active. After that, the collaborator also found some students did not communicative when they did the task in pairs, they just busy with themselves without worked together with their friend. Next, there were some students were confused and not understand to the use the technique, so it conditions made the students had not finished their task.

Furthermore, in the lecturer's performance, the lecturer still too fast in sharing the material and the lecturer didn't repeat the explanation about the learning procedure. In addition, the lecturer also did not give enough time for the students to deliver some question about what they didn't understand about the learning activities. Next, the lecturer didn't clear in give a reflection activity in the end of the learning process, even the lecturer forgot to deliver the learning objectives. And then the lecturer could not manage the class well. And then, in class environment, the classroom condition was noisy and untidy, because some students looked dominated in the class. They are busy with their friends and did not focuss to learning activities. It made the class seemed run less effective. As the result, it showed that the class climate was not really excited. The learning looked didn't fun for some student. Those problems made the learning activities still have many weaknesess and the learning procedure did not run well.

\section{The measurement test}


In the first cycle, the researcher was found that many score of students were still poor and very poor. In detail, the researcher would to present in the graph as follow:

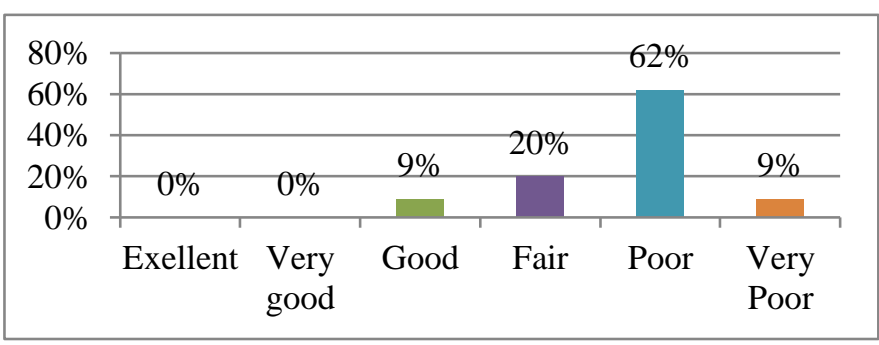

Figure 1. Students' Score Qualification in the first Cycle

Based on the percentage of the diagram above, it can be concluded that the students' qualification score were still unsatified. Where most of students were still poor. It proved that $62 \%$ of students or 21 students still categorized in poor level. Then, $9 \%$ of students or 3 students were categorized in very poor. However, there were only $20 \%$ of students or 7 students categorized in fair condition, and there were $9 \%$ of students or 3 students were categorized as good. Furthermore, based on the writing test result conducted in this first cycle, showed still there were no students categorized in very good and excellent.

\section{The Second Cycle}

\section{Observation checklist}

The result of observation checklist which had been filled by the collaborator was found that a lot of students paid attention to the lecturer explanation about recount text and Peer Editing technique, there was improvement than the first cycle that was good attention of students. And also, a lot of students asked the lecturer about the material. It means that there was improvement than the first cycle.Then, there were a very great deal of students showed interested and enthusiastic in learning process, and also a very great deal of the students in the group more active and communicative, moreover a very great deal of students worked together and analyzed the text in pairs. It means that, in this stage, there was improvement than in first cycle. Furthermore, there were a lot of students that success finished their writing recount text by using Peer Editing technique, and a 
very great deal of students work properly based on the instruction. Then, a very great deal of students asked asked the lecturer when they have difficulties about the materials. Then, a lot of students give response and discuss the draft with their friends and also there were a lot of students asked about learning process during make a recount text by using Peer Editing. It means that, in this stage also there were improvements than the first cycle.

For the next, the lecturer performance was better than cycle before. The lecturer explained and explored all about recount text, and monitors the students during learning the task and also the lecturer did a reflections activity. Furthermore, in the class environment, the class situation was tidy and not noisy. The class climate also looked joyful and fun, and there were a good interaction between students to students and students to the lecturer. It means that, in the lecturer performance and the class environment there was improvement than first cycle.

\section{Field note}

There were some notes that collaborator found during learning teaching process applied in the second cycle. In the field note also still consist of students' performance, lecturer's performance and class environment. In the students' performance, it showed that there was a positive improvement of the students in the learning activities. Most of students looked enthusiastic and active followed the lecturer explanation. The students also more active to ask and answer the questions by lecturer. Then, the students look easier to construct writing and also the students look enthusiastic during writing activities. Furthermore, in the lecturer performance, the lecturer also had done the greats improvement than first cycle. The lecturers had explained not to fast and repeated back again. As the result, students became easier in understanding the material. Lecturer also gave an enough opportunity to students to asked about the material. Then, the lecturer monitors all students' activities well and also, the lecturer used joyful media so that students feel enjoyed the class.

Then, For the class environment, some noted by the collaborator, which is during the class, the atmosfer looked better than first cycle. Because the class 
environtment was fun. Almost all student enjoyed the learning process and the class condition was tidy and not noisy. That was make the lecturer became better in controlled and monitor all the students. Based on the data of observation checklist and field note above, it could be concluded that there was improvement in learning process by using Peer Editing technique. From the data above, there were almost all of students were communicative, active, and enthusiastic and felt joyful and fun during learning writing recount text by using Peer Editing technique.

\section{The measurement test}

In the second cycle, the researcher was found that score of students were good. In detail, The Researcher would to present in the graph as follow:

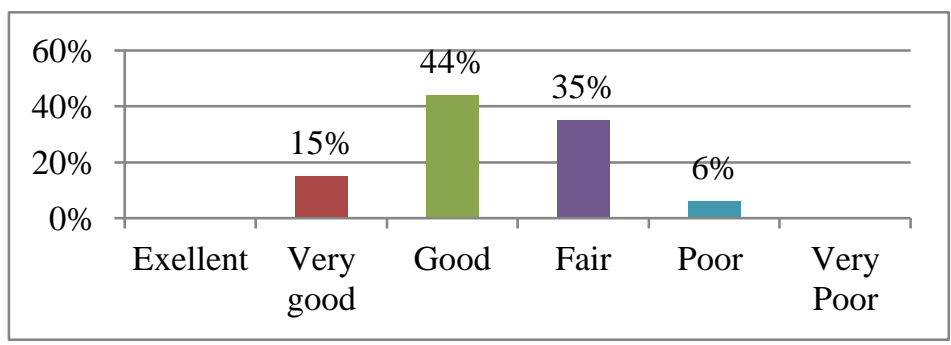

Figure 2. Students' Score Qualification in the Second Cycle

From the percentage of the diagram above, it can be seen that the students' score qualification was improved from the first cycle. In this second cycle, there is a great improvement of the students' score. It proved by the data showed on the figure above which $15 \%$ of students or 5 students categorized as very good. Then, $44 \%$ of students or 15 students was categorized as good. Next, $35 \%$ of students or 12 students was categorized as fair. In this second cycle, Only $6 \%$ of students or 2 students were categorized as poor. In addition, there is no students who categorized as very poor. In conclusion, in this cycle the students' score showed an improvement, although there were still some students who categorized in poor level in term of students score qualification.

\section{The students' mean score}


Based on the test result of every cycle, it was found that the mean score of students had improved from cycle to cycle. It can be seen on the graph below:

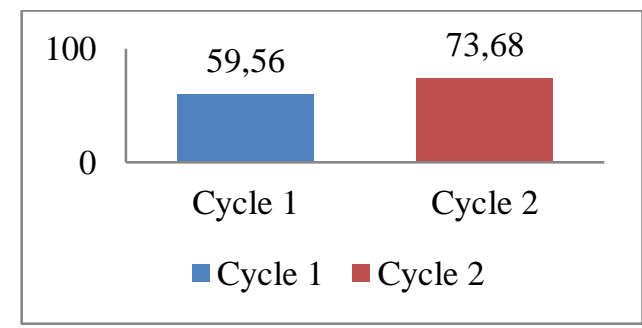

Figure 3 The students' mean score

Based on the figure above. From the test result in each cycle, it was found that the mean score of students had improved from first cycle to second cycle. It proved from the result of students' mean score in the first cycle was 59.56 which were still as unsatified result. Then, in the second cycle, the improvement of students could be seen from the mean score which increase to 73.68 which could be categorized as a good result.

\section{DISCUSSION}

Based on qualitative and quantitative data findings during this research, The result of observation cheklist showed that the students' had the positive improvement from first cycle until second cycle of research. In the first cycle, the students looked bored in learning writing process, they look could not involved in the learning process. As the result, some of them seems confused about what they have to do. It is because the researcher less of prepared the class well. So that in the second cycle, The Researcher as the lecturer tried took the students active by presented the interesting material, then the students asked actively answered the questions by the lecturer. As the result the lecturer brought the students enthusiastic during the learning writing process than first cycle.

The result from field note in the first cycle, there were some notes by the collaborator, such The Researcher still too fast in his explanation. Then, the researcher also still could not control class as well. So that to cope these weaknesses The Researcher conduct the second cycle. In the second cycle, The Researcher did an explanation in slowly, did repeated the expalpantion twice, researcher also did monitor all the students activities well. Then, the quantitative 
data that was obtained from the students' writing test, where this showed that the students had showed good improvement too. It proved from the individual score of students' writing test from first cycle and second cycle of research. Reviewed the implementation of Peer Editing technique in the first cycle, the most of the students' problem was the students confused in gave respond to their friend draft. Because, they not too understand about the grammar, content, vocabulary, organization and mechanics. Richard (2002:303), stated "second language (L2) writers have to pay attention to higher level skills of planning and organizing as well as lower level skills of spelling, punctuation, word choice, and so on." So that to minimize the problems the researcher did explain them back how to use the correct grammatical in writing process such the correct grammar, mechanic, word choice etc.

The researcher also helped them when they had confused. As the result, the students' writing in the second cycle showed a good improvment than first cycle. Means in their writing, they became could used the correct grammar, speeling, word choice etc as well. Through the implementation of Peer Editing technique, the students maximize their performances in their writing since they are going to be ashamed to have many mistakes on their writing hence their writing skills are improved. Moreover, each student is now also able to be more care of their friends' writing since they are assigned to read, to pay attention and then, to give responses to their friends' writing. In line with Hutton (2011), Having students give feedback to one another on their papers can have many advantages: the students get opportunities to develop their ability to give constructive feedback, they receive advice on their drafts, they have a broader audience for their work than just a single instructor, and they see different approaches other students have taken in responding to an assignment.

In addition, the various activities and tasks in the cycles had also supported and helped the students in enhancing students' audience awareness and enabling the students to see egocentrism in their writing and help the students' critical reading and analysis skills (Liu and Hansen in Kitchakarn 2009:72). From the result above, peer editing technique encouraged the students to focus on the 
intended meaning by discussing the alternative points of view that led to the development of ideas, promote more at the student's level of development and interests by providing more informative messages than teacher feedback, and make the students' attitudes towards writing could be enhanced with the help of the supportive peers and they assumed to be more responsible for the writing as well.

\section{CONCLUSIONS}

The researcher got conclusions Peer Editing technique could improve the students' writing recount text. This statement was proven by the result of research findings in qualitative and quantitative data. This improvement happened because of Peer Editing was a teaching technique that relevant to solve and improve students' problem in writing recount text which this technique use the respond to correct the draft, so it make the students easier and help the students to write a recount text, and then in teaching and learning process, the students were active, communicative and enthusiastic.

\section{REFERENCES}

Ary, Donald et all. 2010. Introduction to Research in Education. Canada: Nelson Education, Ltd.

Bartels, Nat. 2003. Written Peer Response In L2 Writing. English Teaching Forum. Germany. 34-37

Bell, S. 1999. A Beginners Guide to Uncertainty of Measurement. United Kingdom: National Physical Laboratory.

Brown, H. D. 2000. Teaching by Principles: An Interactive Approach to Language Pedagogy (2nd Ed.). New York: Addison Wesley Longman, Inc.

Burns, Anne. 1999. Collaborative Action Research for English Language Teacher. United Kingdom: The Press Syndicate of The University of Cambridge.

Celce-Murcia, Morianne. 2001. Teaching English as A Second or Foreign Language.(3rd Edition).Boston: Heinle \& Heinle Publishing.

Farianti, Ratna Ika. 2013 . Improving Grade Eleven Students' Writing Skills In English Teaching And Learning Process Through Peer Editing. Yogyakarta: State University Of Yogyakarta. 
Fatoni, Rochman Nur. 2014. Using Peer Response To Improve Writing Ability Of Grade Viii Students. Yogyakarta: State University Of Yogyakarta.

Fraenkel et al. 2012. How to Design and Evaluate Research in Education. New York: McGraw-Hill, a business unit of The McGraw-Hill Companies, Inc.

Hutton, Lizzie. 2011. Using Peer Review to Improve Student Writing. Retrieved on August, 30th 2016. http://textlab.io/doc/9114775/using-peer-review-toimprove-student-writing.

Hyland, K. 2003. Second Language Writing. United States of America: Cambrigde University Press.

Kitchakarn, Orachorn. 2007. Incorporating Peer Response to Writing Process.Bangkok University.

Kothari, C.R 1990. Research Methodology: Methods and Techniques. New Delhi: New Age International Limited.

Mettetal, G. 2001. "The What, Why and How of Classroom Action Research". The Journal of Scholarship of Teaching and Learning (JoSoTL), 2 (1), 7-13.

Miles, B.W and Huberman, 1994.Qualitative Data Analysis. (2nd edition). London: Sage Publications

Richards, C.J and Farrell, T.S.C. 2011. Practice Teaching: A Reflective Approach.New York: Cambridge University Press.

Ross,N.K 2005. Educational Research: Some Basic Concepts and Terminology. France: International Institute for Educational Planning Inc.

Sudijono, A. 2011. Pengantar Evaluasi pendidikan. Jakarta: RajaGrafindo Persada.

Tomal, R.D 2003. Action research for educators. United States of America: The Scarecrow Press, Inc.

Wessbrook, lynn. 1994. "Qualitative Research Methods: A Review of Major Stages, Data Analysis Techniques, and Quality Controls". Journal of Undergraduate Library, 16, 241-254. 